\title{
INTEGRASI PEMBENTUKAN KARAKTER \\ DALAM PEMBELAJARAN IPS SD
}

\author{
Arni Gemilang Harsanti
}

\author{
Prodi PGSD FIP IKIP PGRI MADIUN \\ glitter.harshanti@gmail.com
}

\begin{abstract}
The ministry of national education (kemendiknas) stated the application of character education in every level from Elementary School to University. It is because during these days, educational world scored less succeed in introducing national generation to become prestige personality. It is implicated through every subject of study, like social studies. The position of social studies learning is so unique because there must be preparation to educate students to live and understand their world, where their personal and social quality will become more important. The developed values in character education are identified by: (1) religion, (2) Pancasila, (3) Cultural, and (4) National education purposes. The value of social studies, a teacher must push the students to become active in obtaining values. Through social studies, students are directed to be democratic and responsible citizen and also world citizen who love peaceful. The subject of social studies is designed to develop science, understanding and analysis ability to social community condition in entering dynamic society life.
\end{abstract}

Keywords : Character Formation, Learning, Social Studies, Basic Education

\begin{abstract}
Abstrak
Kementerian Pendidikan mencanangkan penerapan pendidikan karakter bagi semua tingkat pendidikan mulai sekolah dasar hingga perguruan tinggi. Program ini dicanangkan sebab selama ini dunia pendidikan dinilai kurang berhasil dalam mengantarkan generasi bangsa menjadi pribadi yang bermartabat. Penerapan pendidikan karakter bagi semua tingkat pendidikan mulai sekolah dasar hingga perguruan tinggi dilaksanakan melalui semua mata pelajaran, salah satunya dalam Ilmu Pengetahuan Sosial (IPS). Kedudukan pengajaran IPS begitu unik karena harus mempersiapkan dan mendidik anak didik untuk hidup dan memahami dunianya, dimana kualitas personal dan kualitas sosial seseorang akan menjadi hal yang sangat vital. Nilai-nilai yang dikembangkan dalam pendidikan karakter diindentifikasi dari sumber: (1) agama, (2) pancasila, (3) budaya, dan (4) tujuan pendidikan nasional. Nilai dalam pendidikan IPS, seorang guru harus mendorong anak untuk aktif bertingkah laku sesuai dengan nilai-nilai yang berlaku. Melalui mata pelajaran IPS, peserta didik diarahkan untuk menjadi warga negara Indonesia yang demokratis, dan bertanggung jawab, serta warga dunia yang cinta damai. Mata pelajaran IPS dirancang untuk mengembangkan pengetahuan, pemahaman, dan kemampuan analisis terhadap kondisi sosial masyarakat dalam memasuki kehidupan bermasyarakat yang dinamis.
\end{abstract}

Kata kunci : pembentukan karakter, pembelajaran, IPS, pendidikan dasar 



\section{A. Pendahuluan}

Pembukaan

Undang-

Undang Dasar Negara Republik

Indonesia Tahun 1945 yang merupakan salah satu hukum tertinggi di Indonesia mengamanatkan pemerintah mengusahakan dan menyelenggarakan satu sistem pendidikan nasional yang meningkatkan keimanan dan ketakwaan kepada Tuhan Yang Maha Esa serta akhlak mulia dalam rangka mencerdaskan kehidupan bangsa.

Dalam rangka mencerdaskan kehidupan bangsa sesuai dengan Pembukaan Undang-undang Dasar Tahun 1945 alinea ke empat pemerintah menyelenggarakan program pendidikan, yang kemudian dirumuskan dalam pendidikan nasional. Tujuan dilaksanakan pendidikan nasional sebagaimana yang terdapat di dalam Undangundang Sistem Pendidikan Nasional No 20 Tahun 2003 bahwa Pendidikan Nasional berfungsi mengembangkan kemampuan dan membentuk watak serta peradaban bangsa yang bermartabat dalam rangka mencerdaskan kehidupan bangsa, bertujuan untuk berkembangnya potensi peserta didik agar menjadi manusia yang beriman dan bertakwa kepada Tuhan Yang Maha Esa, berahklak mulia, sehat, berilmu, cakap, kreatif, mandiri, dan menjadi warga negara yang demokratis serta bertanggung jawab.

Undang-Undang

Sistem

Pendidikan Nasional harusnya membuat kita sadar dan mengerti tujuan serta makna pendidikan yang sesungguhnya. Undang-Undang Sisdiknas Nomor 20 Tahun 2003 yang menyatakan bahwa,"Pendidikan adalah usaha sadar dan terencana untuk mewujudkan suasana belajar dan proses pembelajaran agar peserta didik secara aktif mengembangkan potensi dirinya untuk memiliki kekuatan spiritual keagamaan, pengendalian diri, kepribadian, kecerdasan, akhlak mulia, serta keterampilan yang diperlukan. Sejak tahun 1920-an Ki Hajar Dewantara telah mengumandangkan pemikiran bahwa pendidikan pada dasarnya adalah memanusiakan manusia dalam artian menjadikan perkembangan harkat dan martabat manusia secara optimal (Dantes, 2011). Untuk itu, suasana yang dibutuhkan dunia pendidikan adalah suasana yang berprinsip pada kekeluargaan, kebaikan hati, empati, cinta kasih, dan penghargaan terhadap masing-masing anggotanya.

Dengan demikian, pendidikan ini merupakan pendidikan karakter untuk membantu peserta didik mengembangkan kepribadian, sehat fisik, sehat mental, cerdas, serta menjadi anggota masyarakat yang berguna. Lebih lanjut, dalam pedoman pelaksanaan pendidikan karakter (Kemendiknas, Balitbang, Puskur, 2011) dinyatakan bahwa pendidikan karakter bertujuan membentuk bangsa yang tangguh, 
kompetitif, berakhlak mulia, bermoral, bertoleran, bergotong royong, berjiwa patriotik, berkembang dinamis, berorientasi ilmu pengetahuan dan teknologi yang semuanya dijiwai oleh iman dan takwa kepada Tuhan Yang Maha Esa berdasarkan Pancasila. Pendidikan karakter berfungsi (1) mengembangkan potensi dasar agar berhati baik, berpikiran baik, dan berperilaku baik; (2) memperkuat dan membangun perilaku bangsa yang multikultur; dan (3) meningkatkan peradaban bangsa yang kompetitif dalam pergaulan dunia. Pendidikan karakter dilakukan melalui berbagai media yang mencakup keluarga, satuan pendidikan, masyarakat sipil, masyarakat politik, pemerintah, dunia usaha, dan media masa dirinya, masyarakat, bangsa dan negara.

Berdasarkan

tujuan pendidikan nasional tersebut, maka idealnya lulusan satuan pendidikan memiliki kompetensi sikap yang meliputi sikap spiritual (beriman dan bertakwa kepada Tuhan Yang Maha Esa), dan sikap sosial (berakhlak mulia, sehat, mandiri, demokratis, bertanggung jawab), pengetahuan (berilmu) dan keterampilan (cakap dan kreatif). Namun, faktanya dunia pendidikan kita dewasa ini hanya mampu melahirkan lulusan-lulusan manusia dengan tingkat intelektualitas yang memadai.
Banyak dari lulusan sekolah yang memiliki nilai tinggi, berotak cerdas, brilian tapi sayangnya tidak sedikit pula diantara mereka yang cerdas itu justru tidak memiliki perilaku cerdas dan sikap yang brilian serta kurang mempunyai mental kepribadian yang baik (Aunillah, 2011). Pernyataan tersebut dibuktikan dengan banyaknya persoalan yang muncul di masyarakat seperti korupsi, kekerasan, kejahatan seksual, perusakan, perkelahian massa, penyalah gunaan narkoba, kehidupan ekonomi yang konsumtif, kehidupan politik yang tidak produktif, dan sebagainya.

Fenomena tersebut jelas menimbulkan kekhawatiran tersendiri bagi banyak kalangan. Apa jadinya jika negeri ini memiliki banyak orang cerdas, namun ternyata mental dan perilaku mereka sama sekali tidak cerdas? Bahkan, tidak ada korelasi antara tingginya nilai yang diperoleh di bangku pendidikan dengan perilaku mereka di tengahtengah masyarakat. Akibatnya, muncullah sosok-sosok orang pandai yang memperalat orang bodoh atau orang pandai yang menindas orang lemah. Oleh karena itu sejak tahun 2010, pemerintah melalui Kementerian Pendidikan Nasional (Kemendiknas) mencanangkan penerapan pendidikan karakter bagi semua tingkat pendidikan mulai sekolah dasar hingga perguruan tinggi. Program ini dicanangkan sebab selama ini dunia pendidikan dinilai kurang berhasil dalam mengantarkan generasi bangsa menjadi pribadi yang bermartabat. 
Penerapan pendidikan
karakter bagi semua tingkat
pendidikan mulai sekolah dasar
hingga perguruan tinggi
dilaksanakan melalui semua mata
pelajaran, salah satunya dalam
Ilmu Pengetahuan Sosial (IPS).
Kedudukan pengajaran IPS begitu
unik karena harus mempersiapkan
dan mendidik anak didik untuk
hidup dan memahami dunianya,
dimana kualitas personal dan
kualitas sosial seseorang akan
menjadi hal yang sangat vital. Menurut A.K. Ellis (1991), bahwa alasan dibalik diajarkannya IPS sebagai mata pelajaran di sekolah karena. IPS memberikan tempat bagi Anak Didik untuk belajar dan mempraktekan demokrasi. IPS dirancang untuk membantu Anak Didik menjelaskan "dunianya". IPS adalah sarana untuk pengembangan diri Anak Didik secara positif. IPS membantu Anak Didik memperoleh pemahaman mendasar (fundamental understanding) tentang sejarah, geographi, dan ilmu-ilmu sosial lainnya. IPS meningkatkan kepekaan Anak Didik terhadap masalah-masalah sosial.

Melalui pendidikan

karakter IPS diharapkan anak didik dapat mengusai ilmu sosial, sehingga anak didik siap untuk hidup dan menghadapi gejalagejala sosial dan permasalahannya dengan tetap mempertahankan budi pekerti yang luhur.

\section{B. Metode Penelitian}

Penelitian ini adalah library research (penelitian kepustakaan), yaitu penelitian yang dilaksanakan dengan menggunakan literatur (kepustakaan), baik berupa buku, catatan, maupun laporan hasil penelitian.

\section{Data dan Sumber Data}

Sebagaimana pemikiran M. Iqbal Hasan (2002), studi dokumentasi adalah tehnik pengumpulan data yang tidak langsung ditujukan pada sebuah penelitian, namun melalui dokumen. Dokumen yang digunakan dapat berupa buku harian, surat pribadi, laporan, notulen rapat, catatan khusus dalam pekerjaan sosial dan dokumen lainnya. Jadi semua dokumentasi diposisikan setara tergantung ketersambungan dengan topik utama penelitian ini.

\section{Teknik Pengumpulan Data}

Teknik pengumpulan data dalam penulisan ini adalah dokumentasi. Metode dokumentasi yaitu metode pengumpulan data melalui benda-benda tertulis, seperti majalah, buku-buku, dokumen, peraturan-peraturan, notulen, rapat, catatan harian dan sebagainya (Arikunto:2010).

Penulis akan melakukan identifikasi wacana dari buku-buku, makalah atau artikel, majalah, jurnal, web (internet), ataupun informasi lainnya yang berhubungan dengan judul penulisan.

\section{E. Analisis Data}

Dalam penelitian ini setelah dilakukan pengumpulan data, maka data tersebut dianalisis untuk mendapatkan 
kesimpulan. Metode analisis yang digunakan dalam penelitian ini adalah analisis deskriptif.

Metode analisis deskriptif yaitu usaha untuk mengumpulkan dan menyususn suatu data, kemudian dilakukan analisis terhadap data tersebut. Analisis deskriptif yakni data yang dikumpulkan adalah berupa katakata, gambar dan bukan angkaangka. Hal ini disebabkan oleh adanya penerapan metode kualitatif. Selain itu, semua yang dikumpulkan berkemungkinan menjadi kunci terhadap apa yang sudah diteliti (Arikunto:2010). Dengan demikian laporan penelitian akan berisi kutipankutipan data dan pengolahan data untuk memberi gambaran penyajian laporan tersebut.

\section{F. Hasil dan Pembahasan}

Bangsa Indonesia pada dasarnya adalah bangsa yang kaya akan sumber daya manusia (SDM). Dengan pendidikan, SDM tersebut dapat dibina dan dididik menjadi SDM yang berkualitas serta dapat mengharumkan nama bangsa Indonesia. Seperti dalam Pembukaan Undang-Undang Negara Republik Indonesia Tahun 1945 mengamanatkan Pancasila sebagai dasar negara dan pandangan hidup bangsa Indonesia. Salah satu misi tersebut yang termuat dalam Garis-Garis Besar Haluan Negara yaitu mewujudkan sistem dan iklim pendidikan nasional yang demokratis dan bermutu guna memperteguh akhlak mulia, kreatif, inovatif, berwawasan kebangsaan, cerdas, sehat, berdisiplin dan bertanggungjawab, berketerampilan serta menguasai ilmu pengetahuan dan teknologi dalam rangka mengembangkan kualitas manusia Indonesia.

Melalui sistem pendidikan yang dilaksanakan di Indonesia, seharusnya Indonesia menjadi negara yang berkembang dengan baik. Dengan rumusan batang tubuh UUD 1945 mengamanatkan bahwa pemerintah mengusahakan dan menyelenggarakan satu sistem pendidikan nasional untuk meningkatkan keimanan dan ketaqwaan kepada Tuhan Yang Maha Esa serta akhlak mulia dalam rangka mencerdaskan kehidupan bangsa.

Indonesia memerlukan sumberdaya manusia dalam jumlah dan mutu yang memadai sebagai pendukung utama dalam pembangunan. Untuk memenuhi sumberdaya manusia tersebut, pendidikan memiliki peran yang sangat penting. Hal ini sesuai yang dinyatakan dalam Undang-Undang No 20 Tahun 2003 tentang Sistem Pendidikan Nasional pada pasal 3, bahwa pendidikan nasional berfungsi mengembangkan kemampuan dan membentuk karakter serta peradaban bangsa yang bermartabat dalam rangka mencerdaskan kehidupan bangsa, bertujuan untuk berkembangnya potensi peserta didik agar menjadi manusia yang beriman dan bertakwa kepada Tuhan Yang Maha Esa, berakhlak mulia, sehat, berilmu, cakap, kreatif, mandiri, dan 
menjadi warga negara yang demokratis serta bertanggung jawab.

Berdasarkan tujuan pendidikan nasional tersebut, maka dibutuhkan pendidikan karakter bagi bangsa Indonesia. Untuk itu melalui Kementerian Pendidikan Nasional (Kemendiknas), Pemerintah mencanangkan penerapan pendidikan karakter bagi semua tingkat pendidikan mulai sekolah dasar hingga perguruan tinggi.

Pentingnya penerapan pendidikan karakter di satuan pendidikan juga diperkuat oleh beberapa hasil penelitian yang menunjukkan bahwa kesuksesan dan kegagalan seseorang disegala aspek kehidupan tidak ditentukan semata-mata oleh pengetahuan dan kemampuan teknis saja, tetapi lebih pada faktor kepribadian atau sikap. Hasil-hasil penelitian yang dimaksud antara lain; hasil penelitian di Universitas Standford menyimpulkan bahwa kesuksesan ditentukan oleh $87,5 \%$ attitude (sikap) dan hanya 12,5\% karena kemampuan akademik seseorang (Mardiansyah dan Senda, 2011). Hal yang sama juga ditunjukkan oleh hasil penelitian dari Institut Teknologi Carnegie yang mengatakan bahwa dari 10.000 orang sukses, $85 \%$ sukses karena faktor kepribadian dan 15\% karena faktor teknis. Demikian pula hasil penelitian Dr.Albert Edward
Wiggam dalam (Mardiansyah dan Senda, 2011)yang menyatakan bahwa dari 4000 orang yang kehilangan pekerjaan, 400 orang (10\%) karena kemampuan teknis, sedangkan 3.600 orang $(90 \%)$ karena faktor kepribadian.

$$
\text { Hasil-hasil penelitian tersebut }
$$
tentunya sangat menarik untuk dicermati. Sebab ternyata faktor utama dari kesuksesan dan kegagalan itu adalah kepribadian atau lebih spesifik lagi adalah sikap dari orang tersebut. Hal ini mengisyaratkan perlunya mengimplementasikan pendidikan karakter di satuan pendidikan untuk membentuk karakter atau perilaku baik peserta didik selain pengetahuan dan keterampilannya.

Pendidikan karakter terdiri dari dua kata, yakni pendidikan dan karakter. Kedua kata ini memiliki arti dan makna yang berbeda. namun ketika digabungkan akan memiliki makna dan semangat lain hingga memiliki kekuatan tersendiri untuk mengubah kepribadian anak. Jika dilihat Kamus Bahasa Indonesia (Kemendiknas:2010) pendidikan adalah proses pengubahan sikap dan tata laku seseorang atau kelompok orang dalam usaha mendewasakan manusia melalui upaya pengajaran dan pelatihan. Sedangkan menurut Undang-Undang No.20 Tahun 2003 tentang Sistem Pendidikan Nasional, pendidikan adalah usaha sadar dan terencana untuk mewujudkan suasana belajar dan proses pembelajaran agar peserta didik secara aktif mengembangkan potensi dirinya untuk memiliki kekuatan spiritual keagamaan, 
pengendalian diri, kepribadian, kecerdasan, akhlak mulia, serta keterampilan yang diperlukan dirinya, masyarakat, bangsa dan negara. Jadi pendidikan mengandung arti proses dalam membina, melatih, memelihara anak atau siapa pun sehingga menjadi manusia yang santun, cerdas, kreatif, berguna bagi diri, keluarga, masyarakat dan bangsa.

Sementara Karakter jika dilihat Kamus Bahasa indonesia (Kemendiknas:2010), berarti sifatsifat kejiwaan, akhlak, atau budi pekerti yang membedakan seseorang dengan orang lain. Menurut Munir (2010) karakter dalah sebuah pola, baik itu pikiran, sikap, maupun tindakan yang melekat pada diri seseorang dengan sangat kuat dan sulit dihilangkan. Sudewo (2011) membedakan karakter dengan tabiat, karakter adalah perilaku baik sedangkan tabiat adalah perilaku buruk. Lebih lanjut Sudewo (2011) mengemukakan bahwa karakter adalah kumpulan sifat baik yang menjadi perilaku sehari-hari, sebagai perwujudan kesadaran menjalankan peran, fungsi, dan tugasnya dalam mengemban amanah dan tanggung jawab.

Penyelenggaraan pendidikan karakter di sekolah harus berpijak kepada nilai- nilai karakter dasar, yang selanjutnya dikembangkan menjadi nilai-nilai yang lebih banyak sesuai dengan kebutuhan, kondisi, dan lingkungan sekolah. Menurut para ahli psikologi (Kemdiknas, 2010), beberapa nilai karakter dasar tersebut adalah: cinta kepada tuhan dan ciptaan-Nya (alam beserta isinya), tanggang jawab, jujur, hormat dan santun, kasih saying, peduli, kerjasama, percaya diri, kreatif, kerja keras, pantang menyerah, keadilan dan kepemimpinan, baik dan rendah hati, tolerasi, cinta damai, dan cinta persatuan. Pendapat lain menyatakan bahwa karakter dasar manusia terdiri atas: dapat dipercaya, rasa hormat dan perhatian, peduli, jujur, tanggung jawab, kewarganegaraan, ketulusan, berani, tekun, disiplin, visioner, adil, dan punya identitas.

Pendidikan karakter bukan sekedar mengajarkan mana yang benar dan mana yang salah, lebih dari itu, pendidikan karakter menanamkan kebiasaan (habituation) tentang hal mana yang baik sehingga peserta didik menjadi paham (kognitif) tentang mana yang benar dan salah, mampu merasakan (afektif) nilai yang baik dan biasa melakukannya (psikomotor). Dengan kata lain, pendidikan karakter yang baik harus melibatkan bukan saja aspek "pengetahuan yang baik (moral knowing), akan tetapi juga "merasakan dengan baik atau loving good (moral feeling), dan perilaku yang baik (moral action). Pendidikan karakter menekankan pada habit atau kebiasaan yang terus- menerus dipraktikkan dan dilakukan (Kemendiknas, 2011).

Penerapan pendidikan karakter bagi semua tingkat pendidikan, mulai sekolah 
dasar hingga perguruan tinggi telah dicanangkan oleh pemerintah sejak tahun 2010. Pencanangan ini menurut Aunillah (2011) dilakukan sebab selama ini, dunia pendidikan dinilai kurang berhasil dalam mengantarkan generasi bangsa menjadi pribadi-pribadi yang bermartabat. Dunia pendidikan kita hanya mampu melahirkan lulusan manusia dengan tingkat intelektualitas yang memadai. Banyak dari lulusan sekolah yang memiliki nilai tinggi, cerdas, brilian, serta mampu menyelesaikan soal mata pelajaran dengan sangat cepat, namun sayangnya tidak sedikit diantara mereka tidak memiliki perilaku cerdas serta kurang mempunyai mental kepribadian yang baik. Padahal tujuan pendidikan adalah menjadikan manusia berkarakter, manusia yang mulia, manusia yang manusiawi. Bahkan sejak ribuan tahun yang lalu Socrates pun telah mengemukakan bahwa tujuan paling mendasar dari pendidikan adalah membuat seseorang menjadi good and smart (orang yang memiliki perilaku baik dan cerdas). Oleh karena itu manusia yang terdidik seharusnya menjadi orang bijak yang dapat menggunakan ilmunya untuk hal-hal yang baik dan dapat hidup secara bijak dalam seluruh aspek kehidupan.

Nilai-nilai yang dikembangkan dalam pendidikan karakter diindentifikasi dari sumber: (1) agama, (2) pancasila, (3) budaya, dan (4) tujuan pendidikan nasional (Afandi, 2011). Nilai-nilai untuk pendidikan karakter seperti yang ditunjukkan pada Tabel 1 .

Tabel 1. Nilai dan Deskripsi Pendidikan Karakter

\begin{tabular}{lll}
\hline No. & \multicolumn{1}{c}{ Nilai } & \multicolumn{2}{c}{ Deskripsi } \\
\hline Karakter & Religius & $\begin{array}{l}\text { Pikiran, perkataan, dan tindakan seseorang yang diupayakan } \\
\text { selalu berdasarkan pada nilai-nilai ketuhanan dan/atau ajaran } \\
\text { agamanya }\end{array}$ \\
\hline 2. & Jujur & $\begin{array}{l}\text { Perilaku yang didasarkan pada upaya menjadikan dirinya sebagai } \\
\text { orang yang selalu dapat dipercaya dalam perkataan, tindakan, dan } \\
\text { pekerjaan }\end{array}$ \\
\hline 3. & Toleransi & $\begin{array}{l}\text { Sikap dan tindakan yang menghargai perbedaan agama, suku, } \\
\text { etnis, pendapat, sikap, dan tindakan orang lain yang berbeda dari } \\
\text { dirinya }\end{array}$ \\
\hline 4. & Disiplin & $\begin{array}{l}\text { Tindakan yang menunjukkan perilaku tertib dan patuh pada } \\
\text { berbagai ketentuan dan peraturan }\end{array}$ \\
\hline 5. & Kerja Keras & $\begin{array}{l}\text { Perilaku yang menunjukkan upaya sungguh-sungguh dalam } \\
\text { mengatasi berbagai hambatan belajar dan tugas serta } \\
\text { menyelesaikan tugas dengan sebaik-baiknya }\end{array}$ \\
\hline 6. & Kreatif & $\begin{array}{l}\text { Berpikir dan melakukan sesuatu untuk menghasilkan cara atau } \\
\text { hasil baru dari sesuatu yang telah dimiliki }\end{array}$ \\
\hline 7. & Mandiri & $\begin{array}{l}\text { sikap dan perilaku yang tidak mudah tergantung pada orang lain } \\
\text { dalam menyelesaikan tugas-tugas }\end{array}$ \\
\hline
\end{tabular}




\begin{tabular}{|c|c|c|}
\hline No. & $\begin{array}{l}\text { Nilai } \\
\text { Karakter }\end{array}$ & Deskripsi \\
\hline 8. & Demokratis & $\begin{array}{l}\text { Cara berfikir, bersikap, dan bertindak yang menilai sama hak dan } \\
\text { kewajiban dirinya dan orang lain }\end{array}$ \\
\hline 9. & $\begin{array}{l}\text { Rasa ingin } \\
\text { tahu }\end{array}$ & $\begin{array}{l}\text { sikap dan tindakan yang selalu berupaya untuk mengetahui lebih } \\
\text { mendalam dan meluas dari sesuatu yang dipelajarinya, dilihat, dan } \\
\text { didengar }\end{array}$ \\
\hline 10. & $\begin{array}{l}\text { Semangat } \\
\text { kebangsaan }\end{array}$ & $\begin{array}{l}\text { Cara berpikir, bertindak, dan berwawasan yang menempatkan } \\
\text { kepentingan bangsa dan negara di atas kepentingan diri dan } \\
\text { kelompoknya }\end{array}$ \\
\hline 11. & $\begin{array}{l}\text { Cinta tanah } \\
\text { air }\end{array}$ & $\begin{array}{l}\text { Cara berfikir, bersikap, dan berbuat yang menunjukkan kesetiaan, } \\
\text { kepedulian, dan penghargaan yang tinggi terhadap bahasa, } \\
\text { lingkungan fisik, sosial, budaya, ekonomi, dan politik bangsa; }\end{array}$ \\
\hline 12. & $\begin{array}{l}\text { Menghargai } \\
\text { prestasi }\end{array}$ & $\begin{array}{l}\text { Sikap dan tindakan yang mendorong dirinya untuk menghasilkan } \\
\text { sesuatu yang berguna bagi masyarakat, dan mengakui, serta } \\
\text { menghormati keberhasilan orang lain }\end{array}$ \\
\hline 13 & $\begin{array}{l}\text { Bersahabat/ } \\
\text { komunikatif }\end{array}$ & $\begin{array}{l}\text { Tindakan yang memperlihatkan rasa senang berbicara, bergaul, } \\
\text { dan bekerja sama dengan orang lain }\end{array}$ \\
\hline 14. & Cinta damai & $\begin{array}{l}\text { Sikap, perkataan, dan tindakan yang menyebabkan orang lain } \\
\text { merasa senang dan aman atas kehadiran dirinya }\end{array}$ \\
\hline 15. & $\begin{array}{l}\text { Gemar } \\
\text { membaca }\end{array}$ & $\begin{array}{l}\text { Kebiasaan menyediakan waktu untuk membaca berbagai bacaan } \\
\text { yang memberikan kebajikan bagi dirinya }\end{array}$ \\
\hline 16. & $\begin{array}{l}\text { Peduli } \\
\text { lingkungan }\end{array}$ & $\begin{array}{l}\text { Sikap dan tindakan yang selalu berupaya mencegah kerusakan } \\
\text { pada lingkungan alam di sekitarnya, dan mengembangkan } \\
\text { upayaupaya untuk memperbaiki kerusakan alam yang sudah } \\
\text { terjadi }\end{array}$ \\
\hline 17. & Peduli Sosial & $\begin{array}{l}\text { Sikap dan tindakan yang selalu ingin memberi bantuan pada orang } \\
\text { lain dan masyarakat yang membutuhkan }\end{array}$ \\
\hline 18. & $\begin{array}{l}\text { Tanggung } \\
\text { jawab }\end{array}$ & $\begin{array}{l}\text { Sikap dan perilaku seseorang untuk melaksanakan tugas dan } \\
\text { kewajibannya, yang seharusnya dia lakukan, terhadap diri sendiri, } \\
\text { masyarakat, lingkungan (alam, sosial dan budaya), negara dan } \\
\text { Tuhan Yang Maha Esa }\end{array}$ \\
\hline
\end{tabular}

Meskipun telah dirumuskan 18 nilai pembentuk karakter bangsa, namun tidak menutup kemungkinan bagi pendidik atau satuan pendidikan untuk menambah dengan nilai karakter lain sesuai dengan karakteristik materi maupun kegiatan pembelajaran. Pemilihan nilai-nilai tersebut beranjak dari kepentingan dan kondisi satuan pendidikan masing-masing, yang dilakukan melalui analisis konteks sehingga dalam implementasinya dimungkinkan terdapat perbedaan jenis nilai karakter yang dikembangkan antara satu satuan pendidikan dengan satuan pendidikan yang lain, misalnya nilai karakter yang melekat pada mata pelajaran IPS.

Roberta Woolover dan Kathryn P. Scoot (1987) merumuskan ada lima perspektif dalam mengajarkan IPS . Kelima perspektif tersebut tidak berdiri masing-masing, bisa saja ada yang merupakan gabungan dari perspektif 
186 | Premiere Educandum, Volume 5 Nomor 2, Desember 2015, 177 - 189

yang lain. Kelima perspektif tersebut adalah:

1. IPS diajarkan sebagai pewarisan nilai kewarganegaraan (citizenship transmission).

2. IPS diajarkan sebagai Pendidikan ilmu-ilmu sosial.

3. IPS diajarkan sebagai cara berpikir reflektif (reflective inquiry).

4. IPS diajarkan sebagai pengembangan pribadi Anak Didik.

5. IPS diajarkan sebagai proses pengambilan keputusan dan tindakan yang rasional.

Tujuan pendidikan IPS di tingkat Sekolah Dasar (SD) ditujukan untuk mengembangkan pengetahuan dan ketrampilan dasar Anak Didik yang berguna untuk kehidupan sehari harinya. IPS sangat erat kaitannya dengan persiapan anak didik untuk berperan aktif atau berpartisipasi dalam pembangunan Indonesia dan terlibat dalam pergaulan masyarakat dunia (global society). IPS harus dilihat sebagai suatu komponen penting dari keseluruhan pendidikan kepada anak. IPS memerankan peranan yang signifikan dalam mengarahkan dan membimbing anak didik pada nilai-nilai dan perilaku yang demokratis, memahami dirinya dalam konteks kehidupan masa kini, memahami tanggung jawabnya sebagai bagian dari masyarakat global yang interdependen.

Anak Didik membutuhkan pengetahuan tentang hal-hal dunia luar yang luas dan juga tentang dunia lingkungannya yang sempit. Anak Didik perlu memahami hal-hal berkaitan dengan individunya, lingkungannya, masa lalu, masa kini, dan masa datang. Kesadaran akan pentingnya hubungan antara bahan IPS (social studies content), ketrampilan, dan konteks pembelajaran (learning contexs) dapat membatu kita untuk mengembangkan suatu IPS yang kuat kadar inquiri sosialnya.

Ketrampilan yang perlu dikembangkan dalam pendidikan IPS mencakup hal-hal sebagai berikut:

1. Ketrampilan mendapatkan dan mengolah data

2. Ketrampilan menyampaikan gagasan, argumen, dan cerita

3. Ketrampilan menyusun pengetahuan baru

4. Ketrampilan berpartisipasi di dalam kelompok.

Dalam hubungannya dengan nilai dalam pendidikan IPS, seorang guru harus mendorong anak untuk aktif bertingkah laku sesuai dengan nilai-nilai yang berlaku. Guru perlu memotivasi anak untuk memiliki sikap yang baik. Sangatah penting bagi seorang guru mendorong anak untuk memiliki sikap yang baik, karena dengan menciptakan pengalamanpengalaman di dalam kelas siswa diharapkan akan melakukan perbuatan yang baik dalam kegidupan sehari-harinya. 
Tujuan mata pelajaran IPS di sekolah dasar dari kelas satu sampai kelas enam dirumuskan dalam sejumlah kompetensi yang harus dikuasai. Tujuan tersebut, diajabarkan dalam Standar kompetensi lulusan mata pelajaran Ilmu Pengetahuan Sosial Sekolah Dasar (SD)/Madrasah Ibtidaiyah (MI) yang meliputi:

1. Memahami identitas diri dan keluarga, serta mewujudkan sikap saling menghormati dalam kemajemukan keluarga.

2. Mendeskripsikan kedudukan dan peran anggota dalam keluarga dan lingkungan tetangga, serta kerja sama diantara keduanya.

3. Memahami sejarah, kenampakan alam, dan keragaman suku bangsa di lingkungan kabupaten/kota dan provinsi.

4. Mengenai sumber daya alam, kegiatan ekonomi, dan kemajemukan teknologi di lingkungan kabupaten/kota dan provinsi.

5. Menghargai berbagai peninggalan dan tokoh sejarah nasional, keragaman suku bangsa serta kegiatan ekonomi di Indonesia.

6. Menghargai peranan tokoh pejuang dalam mempersiapkan dan mempertahankan kemerdekaan Indonesia.

7. Memahami perkembangan wilayah Indonesia, keadaan sosial negara di Asia Tenggara serta benua-benua.
8. Mengenal gejala (peristiwa) alam yang terjadi di Indonesia dan negara tetangga, serta dapat melakukan tindakan dalam menghadapi bencana alam.

9. Memahami peranan Indonesia di era global.

Pada jenjang SD/MI mata pelajaran IPS memuat materi Geografi, Sejarah, Sosiologi, dan Ekonomi. Melalui mata pelajaran IPS, peserta didik diarahkan untuk dapat menjadi warga negara Indonesia yang demokratis, dan bertanggung jawab, serta warga dunia yang cinta damai. Mata pelajaran IPS dirancang untuk mengembangkan pengetahuan, pemahaman, dan kemampuan analisis terhadap kondisi sosial masyarakat dalam memasuki kehidupan bermasyarakat yang dinamis. Mata pelajaran IPS disusun secara sistematis, komprehensif, dan terpadu dalam proses pembelajaran menuju kedewasaan dan keberhasilan dalam kehidupan di masyarakat.

Pengetahuan (mengingat) adalah perilaku kognitif yang paling sederhana. Penggunaan istilah-istilah dalam pelajaran IPS memang tidak dapat dihindari, bahkan dapat dikatakan pelajaran IPS kaya dengan istilah, oleh karena itu istilah-istilah dalam IPS harus siap dipanggil kembali dari memori siswa. Untuk mempermudah memori tersebut mudah dipanggil kembali maka pembelajarannya harus ada keterkaitan dengan dunia anak. Cara yang bisa dilakukan ialah dengan mnemonic, membuat web, graphic organizer, dan jalinan sebab akibat. 
Untuk melatih tingkat kognitif yang levelnya lebih tinggi dapat digunakan pembelajaran dengan inquiry. Pembelajaran dengan inquiry adalah pengajaran yang membantu siswa untuk menguji pertanyaan-pertanyaan, issu-issu, atau masalah yang dihadapi siswa dan sekaligus menjadi perhatian guru. Inquiry dapat dilakukan dengan cara: percobaan (experiment), studi kepustakaan (library research), wawancara (interview), dan penelitian produk (product investigation).

\section{G. Kesimpulan}

Undang-Undang Sisdiknas Nomor 20 Tahun 2003 yang menyatakan bahwa,"Pendidikan adalah usaha sadar dan terencana untuk mewujudkan suasana belajar dan proses pembelajaran agar peserta didik secara aktif mengembangkan potensi dirinya untuk memiliki kekuatan spiritual keagamaan, pengendalian diri, kepribadian, kecerdasan, akhlak mulia, serta keterampilan yang diperlukan.

Untuk mewujudkan tujuan Pendidikan Nasional, Pemerintah melalui Kementerian Pendidikan Nasional (Kemendiknas) mencanangkan penerapan pendidikan karakter bagi semua tingkat pendidikan mulai sekolah dasar hingga perguruan tinggi. Program ini dicanangkan sebab selama ini dunia pendidikan dinilai kurang berhasil dalam mengantarkan generasi bangsa menjadi pribadi yang bermartabat.

\section{H. Saran}

Penerapan pendidikan karakter bagi semua tingkat pendidikan mulai sekolah dasar hingga perguruan tinggi dilaksanakan melalui semua mata pelajaran, salah satunya dalam Ilmu Pengetahuan Sosial (IPS). Kedudukan pengajaran IPS begitu unik karena harus mempersiapkan dan mendidik anak didik untuk hidup dan memahami dunianya, dimana kualitas personal dan kualitas sosial seseorang akan menjadi hal yang sangat vital.

$\begin{array}{rrr} & \text { Nilai-nilai yang } & \text { dikembangkan } \\ \text { dalam } & \text { pendidikan } & \text { karakter }\end{array}$ diindentifikasi dari sumber: (1) agama, (2) pancasila, (3) budaya, dan (4) tujuan pendidikan nasional. Nilai dalam pendidikan IPS, seorang guru harus mendorong anak untuk aktif bertingkah laku sesuai dengan nilai-nilai yang berlaku. Sangatah penting bagi seorang guru mendorong anak untuk memiliki sikap yang baik, pengalaman di dalam kelas siswa diharapkan akan melakukan perbuatan yang baik dalam kehidupan sehari-harinya.

Melalui mata pelajaran IPS, peserta didik diarahkan untuk menjadi warga negara Indonesia yang demokratis, dan bertanggung jawab, serta warga dunia yang cinta damai. Mata pelajaran IPS dirancang untuk mengembangkan pengetahuan, pemahaman, dan kemampuan analisis terhadap kondisi sosial masyarakat dalam memasuki kehidupan bermasyarakat yang dinamis. 


\section{Daftar Pustaka}

Abdullah Munir. 2010. Pendidikan Karakter Membangun Karakter Anak Sejak dari Rumah. PT Pustaka Insan Madani. Yogyakarta.

Arikunto, Suharsimi. 2010. Prosedur Penelitian Suatu Pendekatan Praktek Edisi Revisi. Rineka Cipta. Jakarta.

Aunillah, Nurla Isna. 2011. Panduan Menerapkan Pendidikan Karakter di Sekolah. Laksana. Yogyakarta.

Dantes, N. 2011. Pembinaan Guru Profesional Berbasis Karakter. Materi Pendidikan dan Latihan Profesi Guru (PLPG). UNDIKSHA..

Dudi Mardiansyah dan Irawan Senda. 2011. Keajaiban Berperilaku. Tangga Pusaka. Jakarta.

Ellis, K.A. 1991. Teaching and Learning Elementary Social Studies. Needham Heights, MA: Allyn \& bacon.
Hasan, M Iqbal. 2002. Pokok-Pokok Materi Metodologi Penelitian Dan Aplikasinya. Ghalia Indonesia. Jakarta.

Kementerian Pendidikan Nasional. 2010. Kamus Besar bahasa Indonesia. Puskur. Jakarta.

Kementerian Pendidikan Nasional. 2011. Pengembangan Pendidikan Budaya dan Karakter Bangsa. Puskur. Jakarta.

Zuchdi, Prasetyo, Zuhdan, dkk. 2013. Model Pendidikan Karakter. Jl.Wonosari, Mantub. Yogyakarta.

Mulyasa. 2013. Manajemen Pendidikan Karakter. Bumi Aksara. Jakarta.

Sudewo, Erie. 2011. Character Building. PT. Gramedia. Jakarta.

Undang-Undang No 20 Tahun 2003 tentang Sistem Pendidikan Nasional. 